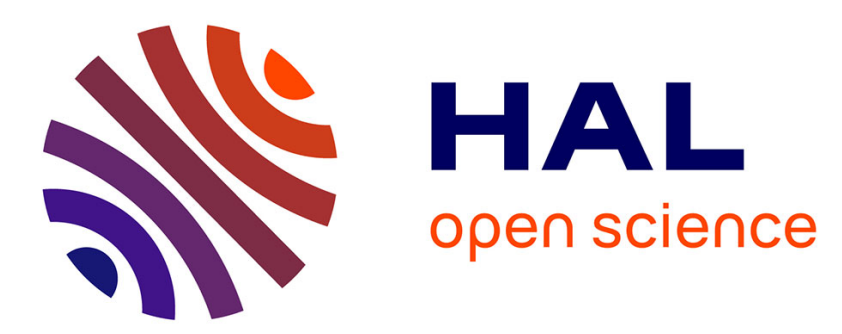

\title{
Evolution of nutricline dynamics in the equatorial Pacific during the late Pliocene
}

\author{
Clara Bolton, Samantha J. Gibbs, Paul A. Wilson
}

\section{To cite this version:}

Clara Bolton, Samantha J. Gibbs, Paul A. Wilson. Evolution of nutricline dynamics in the equatorial Pacific during the late Pliocene. Paleoceanography, 2010, 25 (1), pp.PA1207. 10.1029/2009PA001821 . hal-01668009

\section{HAL Id: hal-01668009 \\ https://hal.science/hal-01668009}

Submitted on 19 Oct 2021

HAL is a multi-disciplinary open access archive for the deposit and dissemination of scientific research documents, whether they are published or not. The documents may come from teaching and research institutions in France or abroad, or from public or private research centers.
L'archive ouverte pluridisciplinaire HAL, est destinée au dépôt et à la diffusion de documents scientifiques de niveau recherche, publiés ou non, émanant des établissements d'enseignement et de recherche français ou étrangers, des laboratoires publics ou privés. 


\title{
Evolution of nutricline dynamics in the equatorial Pacific during the late Pliocene
}

\author{
Clara T. Bolton, ${ }^{1}$ Samantha J. Gibbs, ${ }^{1}$ and Paul A. Wilson ${ }^{1}$ \\ Received 3 July 2009; revised 14 October 2009; accepted 22 October 2009; published 6 March 2010.
}

[1] The tropics have played a central role in modulating Earth's climate throughout the Plio-Pleistocene, with tropical productivity fluctuations a key mechanism in the operation of the global carbon cycle and linkage of high- and low-latitude climates. Published records of tropical sea surface temperatures (SSTs) during the Plio-Pleistocene appear to vary primarily in tune with high-latitude climate on both orbital and secular timescales. However, contemporaneous changes in equatorial primary productivity are less well constrained, particularly at sites where climate is not dominated by upwelling or monsoon systems. Furthermore, the role of thermocline dynamics (tilt and mean depth changes) in forcing SST and productivity on orbital timescales remains uncertain. Here we report new, high-resolution calcareous nannofossil records from two Ocean Drilling Program sites in the western and eastern equatorial Pacific during marine isotope stages 95-101, about 2400-2600 kyr ago. Our records of paleoproductivity and nutricline depth reveal synchronous, largeamplitude glacial-interglacial productivity variations at both ends of the equatorial Pacific indicating (1) remote (high-latitude) forcing of primary productivity and (2) no primary role for east-west tilting of the equatorial Pacific thermocline, with important implications regarding the operation of El Niño-like dynamics in the Pliocene Pacific. Instead, the paleoproductivity variations and phase relationships that we document suggest the interaction of two mechanisms operating on obliquity timescales: a "bottom-up" forcing transmitted via the upwelling of high-latitude source waters in conjunction with the "top-down" forcing of atmospheric greenhouse gases.

Citation: Bolton, C. T., S. J. Gibbs, and P. A. Wilson (2010), Evolution of nutricline dynamics in the equatorial Pacific during the late Pliocene, Paleoceanography, 25, PA1207, doi:10.1029/2009PA001821.

\section{Introduction}

[2] The equatorial Pacific Ocean is a key component of the modern global climate system (1) because of its sheer size; (2) because it is home to the warmest body of water anywhere in the global ocean, the western Pacific warm pool (WPWP); and (3) because it constitutes the world's largest oceanic source of water vapor and $\mathrm{CO}_{2}$ to the atmosphere. Hence, changes in the state of the ocean-atmosphere system across the tropical Pacific have the potential to significantly affect the global carbon cycle on a variety of timescales, from El Niño-Southern Oscillation (ENSO) (see auxiliary material for details) to orbital, by inducing changes in biological production and carbon export, which in turn affect the efflux of $\mathrm{CO}_{2}$ from the equatorial Pacific upwelling regions [Cane, 1998, 2005; Chavez and Barber, 1987; Falkowski et al., 1998; Turk et al., 2001]. ${ }^{2}$ If we are to understand the role of the tropics in amplifying or even driving global climate change, an enhanced understanding of whether the equatorial biological pump is responding to local or remote (high-latitude) forcing is required. To

\footnotetext{
${ }^{1}$ School of Ocean and Earth Science, National Oceanography Centre, Southampton, University of Southampton, Southampton, UK.

Copyright 2010 by the American Geophysical Union. 0883-8305/10/2009PA001821\$12.00
}

date there have been few pre-Pleistocene studies addressing productivity in both the equatorial Pacific "warm pool" and "cold tongue" systems; therefore, our understanding of both mean oceanographic state and dominant forcing mechanisms prior to the evolution of strong eastwest $(\mathrm{E}-\mathrm{W})$ Pacific oceanographic gradients is limited.

[3] Here we reconstruct paleoproductivity at both ends of the equatorial Pacific using nannoplankton communities over three glacial-interglacial (G-IG) cycles key to understanding the climate history of the late Pliocene, marine isotope stages (MIS) 95-101 ( 2400-2600 kyr ago). These G-IG cycles constitute the first large-amplitude $(\sim 1 \%$ Vienna Peedee belemnite (VPDB) in benthic $\delta^{18} \mathrm{O}$ ), obliquity-paced cycles of the Plio-Pleistocene secular cooling trend that postdate the recently hypothesized $\mathrm{CO}_{2}$ drawdown event implicated in the intensification of Northern Hemisphere glaciation [Foster et al., 2008; Lunt et al., 2008] and occur at a time when the modern E-W asymmetry of tropical Pacific oceanographic conditions was significantly reduced (Figure 1). Our records shed new light on paleoproductivity and nutricline depth changes during this important interval and allow us to address the following key questions: (1) To what extent, compared to the modern-day

\footnotetext{
${ }^{2}$ Auxiliary materials are available in the HTML. doi:10.1029/ 2009PA001821.
} 


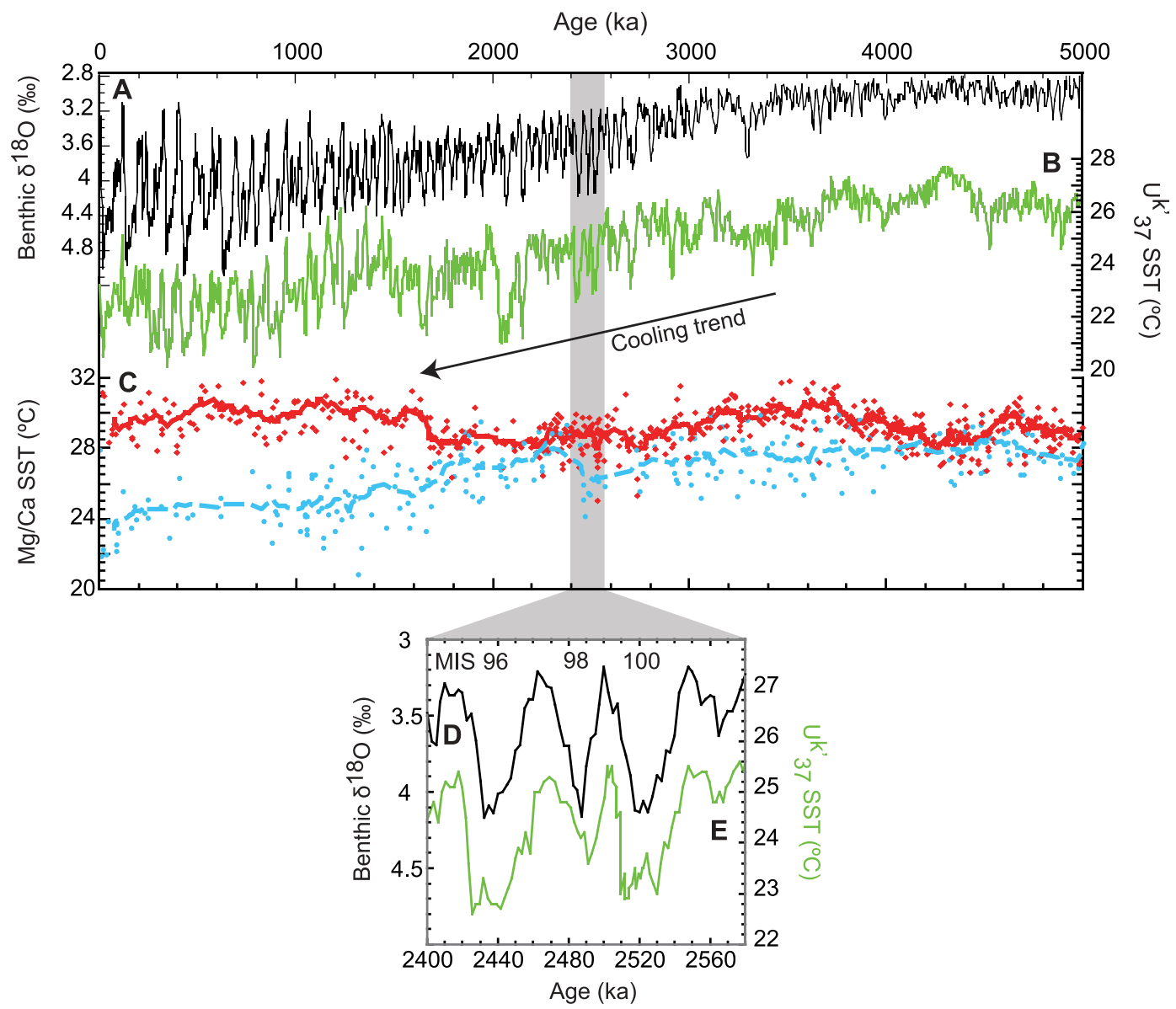

Figure 1. (a) The LR04 global benthic oxygen isotope stack [Lisiecki and Raymo, 2005]. (b) The alkenone unsaturation index $\left(\mathrm{U}_{37}^{\mathrm{k}^{\prime}}\right)$ temperature at ODP Site 846, EEP [Lawrence et al., 2006]. (c) SST records derived from $\mathrm{Mg} / \mathrm{Ca}$ ratios of Globorotalia sacculifer from ODP Site 806 (WEP, red solid line) and ODP Site 847 (EEP, blue dashed line) [Wara et al., 2005]. (d, e) Magnification of the LR04 global benthic oxygen isotope stack and the Site $846 \mathrm{U}_{37}^{\mathrm{k}^{\prime}}$ temperature record over MIS 95-101. Grey shaded area represents the study interval.

situation, was a reduced E-W equatorial Pacific productivity contrast a feature of late Pliocene climate? (2) Did ENSOlike thermocline dynamics operate on obliquity-driven G-IG timescales during the late Pliocene? (3) To what degree are local versus remote mechanisms responsible for late Pliocene productivity forcing? (4) Is high-latitude influence on tropical productivity restricted to areas that are directly linked to polar regions via source waters (upwelling zones)?

\section{Equatorial Pacific Dynamics}

\subsection{Secular Change in Late Neogene Equatorial Pacific Hydrography}

[4] Surface water conditions in the equatorial Pacific Ocean today are characterized by strong $\mathrm{E}-\mathrm{W}$ gradients in SST $\left(\sim 6^{\circ} \mathrm{C}\right)$ and thermocline depth $(\sim 50 \mathrm{~m}$ in the eastern equatorial Pacific (EEP) versus $>150 \mathrm{~m}$ in the western equatorial Pacific (WEP)), with the thermocline and nutricline usually tightly coupled in tropical systems [Bjerknes, 1969; Cane, 2005; Turk et al., 2001]. However, this E-W asymmetry central to modern equatorial Pacific dynamics (see auxiliary material) does not appear to have been a longlived feature of Earth's history. In fact, as recently as the early Pliocene warm period, 3-5 Myr ago, the mean state in the equatorial Pacific appears to have been one akin to modern-day El Niño conditions, with weak to nonexistent E-W SST gradients until around 2.3 Myr ago. These gradients attained their modern strength only around $1.7 \mathrm{Myr}$ ago (Figure 1c) [Barreiro et al., 2006; Ravelo et al., 2006; Wara et al., 2005]. This early Pliocene state has been dubbed "permanent El Niño," but it is important to note that this label refers to mean conditions and does not imply a lack of higher-frequency climate variability on ENSO timescales, variability which is clearly expressed in recent coupled numerical model experiments [Haywood et al., 2007]. Other modeling experiment results suggest that the mechanism responsible for the existence of mean El Niñolike conditions during the early Pliocene involves the maintenance of a deep tropical thermocline [Fedorov et al., 2006; Philander and Fedorov, 2003]. Mean state El Niño- 


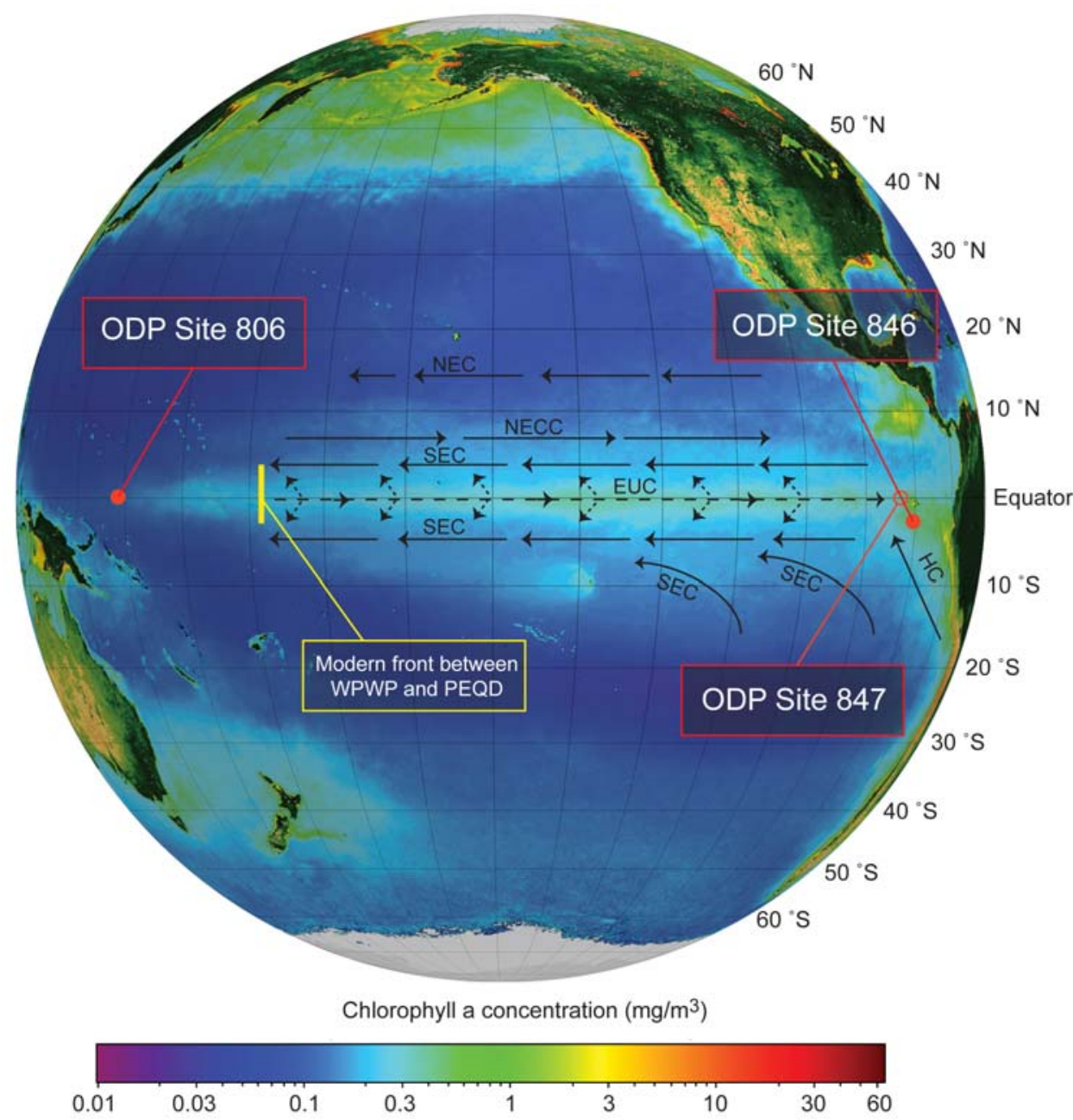

Figure 2. Map of ocean color in the modern tropical Pacific displaying the location of sites used in this study (solid circles), sites discussed (open circle), and main equatorial ocean currents (circulation adapted from Kessler [2006]): North Equatorial Current (NEC), North Equatorial Countercurrent (NECC), South Equatorial Current (SEC), Equatorial Undercurrent (EUC), and Humboldt Current (HC). Dashed arrows represent subsurface currents, and solid arrows represent surface currents. Ocean color data are derived from the Sea-viewing Wide Field-of-View Sensor (SeaWiFS) satellite data (http://seawifs.gsfc.nasa.gov/ SEAWIFS.html) (during boreal autumn and austral spring over the period 1997-2007) and record Chlorophyll $a$ concentration. Ocean color is therefore representative of phytoplankton productivity and illustrates the contrast between the high-productivity EEP and equatorial divergence region and the oligotrophic WEP. The yellow bar shows the estimated modern-day position of the front between the west Pacific warm pool (WPWP) and the Pacific Equatorial Divergence (PEQD).

like conditions may have terminated as a result of long-term deep ocean cooling inducing a gradual shoaling of the tropical thermocline. A threshold response to this slow forcing is thought to have resulted in the emergence of cool tropical upwelling zones around $3 \mathrm{Ma}$.

\subsection{Tropical Climate Change on Orbital Timescales}

\subsubsection{Models}

[5] A mechanism involving changes in thermocline dynamics may also have operated on obliquity-driven G-IG timescales between approximately 3 and $1 \mathrm{Ma}$ [Fedorovet al., 2006; Philander and Fedorov, 2003]. In this hypothesis, obliquity maxima (interglacials) are associated with reduced oceanic heat loss in higher latitudes because of maximum solar insolation. The constraints imposed by a balanced global heat budget result in a deepening of the tropical thermocline and a switch to an El Niño-like state in the equatorial Pacific. During obliquity minima (glacials), a La Niñalike state is induced in the tropics because of greater heat loss at high latitudes, resulting in a shallower thermocline, and greater heat gain in low-latitude upwelling zones. Crucially, this hypothesis of obliquity-driven changes in a mean state implies both (1) fluctuations in the average depth of the thermocline across the whole Pacific basin 

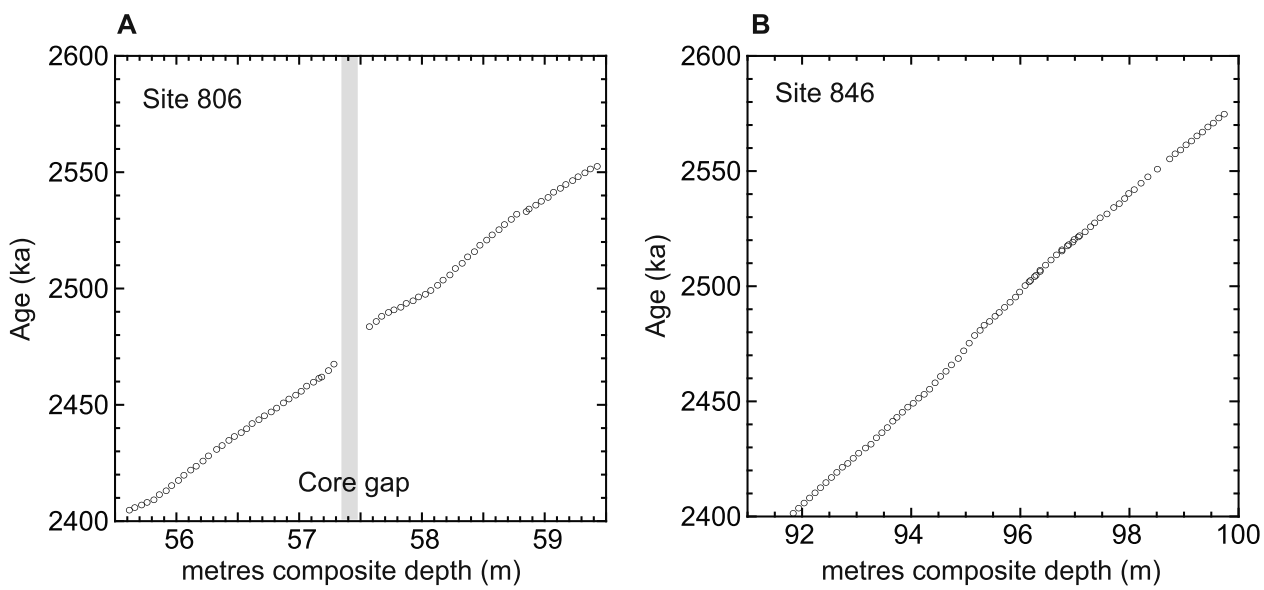

Figure 3. Age models for (a) ODP Site 806 and (b) ODP Site 846 based on the tuning of their benthic isotope stratigraphies (Karas et al. [2009] and Shackleton et al. [1995], respectively) to the LR04 benthic oxygen isotope stack [Lisiecki and Raymo, 2005]. The break at $\sim 2475 \mathrm{ka}$ represented by a grey bar in the ODP Site 806 record results from a coring gap.

and (2) some degree of E-W seesawing of the tropical Pacific thermocline, similar to that observed on shorter timescales during climate instabilities related to ENSO [Fedorov et al., 2006].

\subsubsection{Records}

[6] During the early Pleistocene and Pliocene, when G-IG cycles were predominantly paced by obliquity, tropical paleoproductivity records from sites known to be influenced by monsoon and river systems are dominantly paced by precession [Cleaveland and Herbert, 2007; Gibbs et al., 2004a]. In contrast, paleoproductivity records from the EEP and the eastern equatorial Atlantic (EEA) upwelling regions are tightly coupled to SST records and show strong variance in the obliquity band [Cleaveland and Herbert, 2007; Gibbs et al., 2004a; Lawrence et al., 2006; Liu and Herbert, 2004; Mayer et al., 1992; Mix et al., 2003]. This result from the equatorial oceans implies strong linkages between high- and low-latitude climates during the $41 \mathrm{kyr}$ old world when, if anything, one might expect weaker highlatitude influence on tropical climate than in the late Pleistocene because of smaller contemporaneous ice budgets. However, it is not clear whether this strong connection between high-latitude climate and low-latitude productivity is restricted to environments where polar-sourced waters exert a major influence over surface water properties or whether obliquity-paced changes are a pervasive feature of equatorial productivity.

\section{Materials and Methods}

\subsection{Site Descriptions and Oceanographic Settings}

[7] We selected two equatorial Pacific sites to provide a direct comparison between the western warm pool and the eastern cold tongue (Figure 2). Ocean Drilling Program (ODP) Site 806 is located in the modern WPWP on the northeastern margin of the Ontong Java Plateau at a water depth of $2523 \mathrm{~m}$ (latitude, $0^{\circ} 19.1^{\prime} \mathrm{N}$; longitude, $159^{\circ} 21.7^{\prime} \mathrm{E}$ ), well above the regional lysocline located at approximately $3400 \mathrm{~m}$ [Berger et al., 1982]. ODP Site 846 is located $300 \mathrm{~km}$ due south of the Galapagos Islands on the southern edge of the Carnegie Ridge (latitude, $3^{\circ} 5.7^{\prime} \mathrm{S}$; longitude, $90^{\circ}$ $49.07^{\prime} \mathrm{W}$; water depth, $3296 \mathrm{~m}$ ), near the regional lysocline estimated at $3200 \mathrm{~m}$ [Hagelberg et al., 1995]. Site 846 is located in the EEP cold tongue, where the Humboldt Current and the Southern Equatorial Current merge (Figure 2). The shoaling of the Equatorial Undercurrent (EUC) and advection of water from the eastern boundary current flowing along the Peru-Chile margin result in the upwelling of cool, nutrient-rich water in this region of the EEP. ODP sites 806 and 847 , the latter being close to Site 846 in the EEP, have been previously examined in order to understand the evolution of E-W temperature gradients [Wara et al., 2005].

\subsection{Age Models and Sampling}

[8] Age models (Figure 3) were constructed by tuning the benthic $\delta^{18} \mathrm{O}$ stratigraphies of both ODP sites (Site 806, Karas et al. [2009]; Site 846, Shackleton et al. [1995]) to the Lisiecki-Raymo 2004 (LR04) global benthic oxygen isotope stack [Lisiecki and Raymo, 2005] using AnalySeries [Paillard et al., 1996]. Average sedimentation rates at sites 806 and 846 during the interval of study were $2.8 \mathrm{~cm} / \mathrm{kyr}$ and $5.3 \mathrm{~cm} / \mathrm{kyr}$, respectively. Site 806 was sampled at $5 \mathrm{~cm}$ intervals and Site 846 was sampled at $10 \mathrm{~cm}$ intervals, resulting in an average temporal resolution of approximately 2 kyr for both sites.

\subsection{Nannofossil Counts}

[9] Whole assemblage calcareous nannofossil counts (i.e., all species were counted) were carried out following the counting strategies of Backman and Shackleton [1983] and Flores et al. [1995] from smear slides prepared using standard techniques [Bown and Young, 1998], and all counts were performed on a cross-polarizing microscope at $1500 \mathrm{X}$ magnification. In a first count, all specimens were counted 
from a minimum of eight fields of view (FOVs) until a statistically significant total of at least 450 nannofossils was obtained. A second count was performed from an additional approximately $40 \mathrm{FOVs}$ or 100 less common individuals in order to better quantify the relative abundances of the less common taxa, i.e., those with abundances $<2 \%$ in the first count. The taxonomy of Perch-Nielsen [1985] and Young [1998] was followed throughout. The number of terrigenous particles, foraminifera fragments, and siliceous fragments $(>1 \mu \mathrm{m})$ were also counted in the FOVs of the first count. These were normalized to nannofossil abundances by dividing the number of, for example, siliceous fragments by the number of nannofossils counted in the same FOV.

\subsection{Nannofossil-Based Indicators of Oceanographic Change and $\mathrm{CaCO}_{3}$ Dissolution}

[10] To highlight the main trends in the assemblage, data are presented as individual species or as grouped genera. Species groupings were made on the basis of taxonomic and paleoecological affinities in the modern ocean and inferences from the fossil record (Table S1). We focus on a "cool mesotrophic" rather than a "warm oligotrophic" group because the mesotrophic species present in our Pliocene samples are more consistently associated with specific conditions in both the modern ocean and the fossil record than their oligotrophic counterparts. Included in this coolwater mesotroph group are Reticulofenestra species $(>3 \mu \mathrm{m})$, Calcidiscus species, Coccolithus pelagicus, and Pseudoemiliania species (Table S1). Small $(<3 \mu \mathrm{m})$ placolith-bearing coccoliths from the Noelaerhabdaceae family are hereafter termed very small Reticulofenestrids (VSR). VSR relative abundances were used in conjunction with Florisphaera profunda (Fp) abundances to monitor nutricline depth by producing the so-called $N$ ratio, following the work by Flores et al. [2000] as applied to the equatorial Atlantic and subsequently also applied to the EEP [López-Otálvaro et al., 2008]. The similar dissolution susceptibilities of VSR and $F$. profunda indicate that the ratio between them is unlikely to be significantly skewed by differential dissolution [Gibbs et al., 2004b]:

$$
N=\frac{\mathrm{VSR}}{(\mathrm{VSR}+\mathrm{Fp})}
$$

The relative abundance of $F$. profunda has been successfully applied to reconstruct changes in primary production [Beaufort et al., 1997, 2001; de Garidel-Thoron et al., 2001] and nutricline depth [Flores et al., 2000; LópezOtálvaro et al., 2008; Molfino and McIntyre, 1990] in tropical systems during the Pleistocene to Recent because of its specific depth habitat. $F$. profunda inhabits the lower photic zone $(\sim 60-180 \mathrm{~m})$ and is thus most relatively abundant when surface waters are oligotrophic and upper photic zone productivity is low.

[11] We experimented with a number of nannofossilbased preservation indices as proxies for $\mathrm{CaCO}_{3}$ dissolution, including the ratio of Discoaster fragments to whole Discoaster, a ratio of dissolution-susceptible to dissolutionresistant nannofossil species, and the level of disarticulation in Calcidiscus leptoporus shields. The latter provided the best way to decouple variations attributable to dissolution from those attributable to ecological variations. This dissolution index (DI) is based on the ratio of isolated (IS) to articulated (AS) C. leptoporus shields following McIntyre and McIntyre [1971] and applied by Matsuoka [1990], Findlay and Giraudeau [2002], and Blaj et al. [2009] using the formula

$$
\mathrm{DI}=\frac{\mathrm{IS}}{(\mathrm{IS}+\mathrm{AS})}
$$

\subsection{Spectral and Cross-Spectral Analyses}

[12] Spectral analyses were carried out to investigate whether significant orbital frequencies were present in the data using the Singular Spectrum Analyses-MultiTaper Method (SSA-MTM) Toolkit, version 4.4, software specifically designed to analyze short, noisy time series [Ghil et al., 2002]. Data from both sites were interpolated to achieve a constant sampling resolution of $2 \mathrm{kyr}$, as close as possible to the original resolution of the data. Cross-spectral analyses were carried out using the Arand time series analysis software [Howell et al., 2006] in order to quantify phase lags between records.

\section{Results and Discussion}

\subsection{No Evidence for Strong Assemblage Control by Dissolution}

[13] Several lines of evidence indicate that our equatorial Pacific nannofossil assemblage patterns are not controlled by dissolution. First, whereas $\mathrm{CaCO}_{3}$ accumulation at Site 846 shows strong G-IG cyclicity with $\mathrm{CaCO}_{3}$ minima occurring during glacials [Mix et al., 1995], our DI at both sites shows no systematic G-IG change or correlation with the Site $846 \mathrm{CaCO}_{3}$ record (Figure 4). This implies that changes in the ratio of carbonate to noncarbonate material rather than dissolution are responsible for the structure of the $\mathrm{CaCO}_{3}$ record. Second, both dissolution-susceptible and dissolution-resistant species display abundance peaks during carbonate minima (glacials) (Figure S1). Third, siliceous fragment counts carried out simultaneously with calcareous nannofossil counts in this study indicate higher siliceous productivity during glacials (C. T. Bolton et al., Glacialinterglacial productivity changes recorded by alkenones and microfossils in late Pliocene eastern equatorial Pacific and Atlantic upwelling zones, submitted to Earth and Planetary Science Letters, 2009), suggesting that dilution by biogenic opal is controlling G-IG variability in the Site 846 percent $\mathrm{CaCO}_{3}$ record. Fourth, at nearby Site 847 (water depth, $3334 \mathrm{~m}$ ) (Figure 2), the $\mathrm{CaCO}_{3}$ record shows a strong negative correlation with opal content and no correlation with a foraminiferal fragmentation index, implying that productivity is responsible for the structure of this $\mathrm{CaCO}_{3}$ time series [Murray et al., 1995]. 


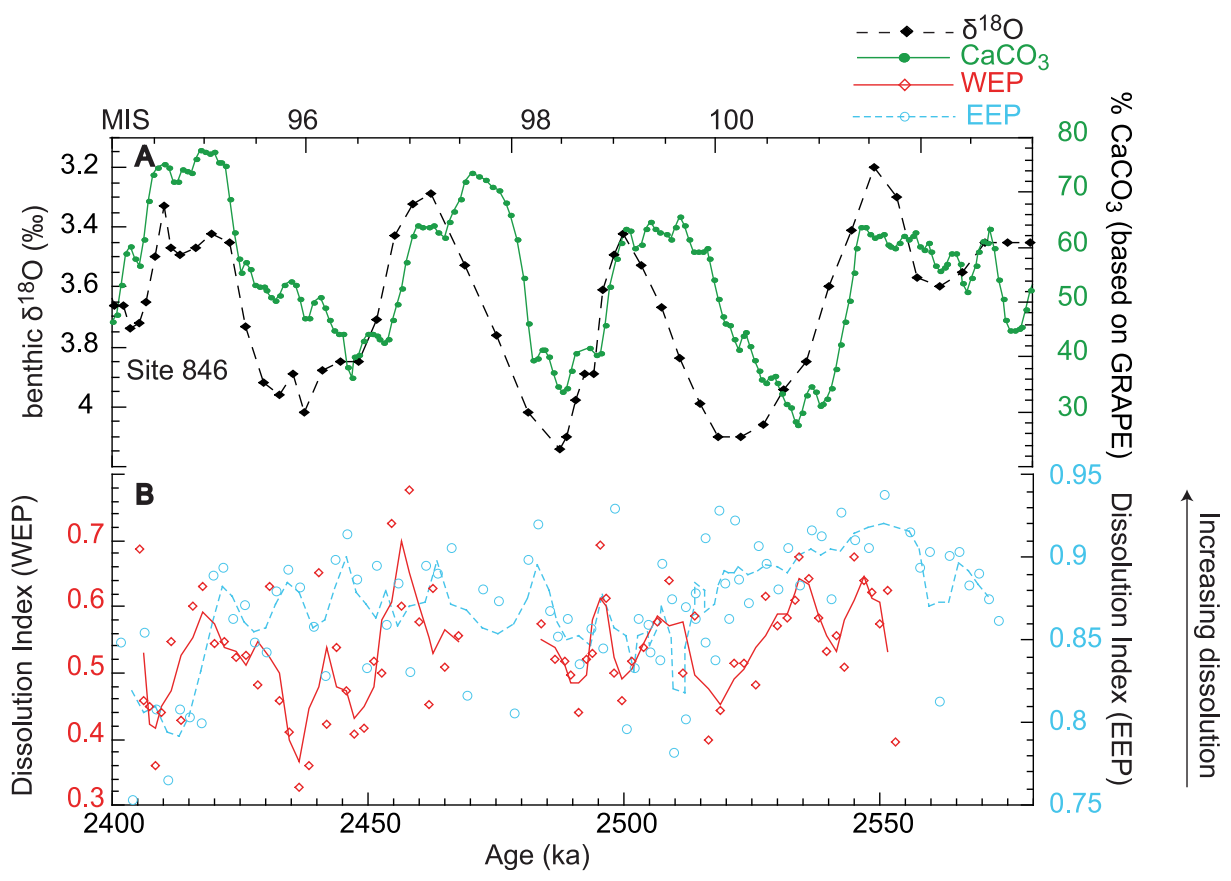

Figure 4. (a) Benthic oxygen isotope record [Shackleton et al., 1995] (black dashed line) and percent $\mathrm{CaCO}_{3}$ record [Mix et al., 1995] (green solid line) at ODP Site 846. (b) Dissolution index at ODP Site 806 (red diamonds and red solid line) and Site 846 (blue circles and blue dashed line). All raw data (symbols) are smoothed with a three-point running mean (lines). MIS is marine isotope stage.

\subsection{Reduced E-W Productivity Contrast During the Late Pliocene}

[14] We identify a total of 28 and 29 calcareous nannofossil species in the WEP and the EEP, respectively, with a similar, diverse nannofossil assemblage found at both sites. Both assemblages are dominated by VSR and $F$. profunda and include species of the genera Reticulofenestra, Pseudoemiliania, Calcidiscus, Discoaster, Helicosphaera, Pontosphaera, Umbilicosphaera, Coccolithus, Syracosphaera, and Thoracosphaera (Figure 5). The similar species richness at both sites is in contrast to late Pleistocene Pacific nannofossil assemblages, which show greater disparity between the EEP and the WEP in terms of both species diversity and relative contributions to the assemblage [Chiyonobu et al., 2006].
[15] All of our floral data from both sites indicate enhanced productivity during glacials compared to interglacials (Figures 6 and 7). The $N$ ratio nutricline depth index indicates a shallower nutricline and therefore higher productivity during glacials compared to interglacials at both Pacific end-members (Figure 6), with G-IG variability of similar magnitude at both sites. Consistent with the $N$ ratio data, the cool-water mesotroph group shows greater relative abundance during glacials than interglacials at both sites and constitutes a larger proportion of the assemblage in the EEP $(14 \%-39 \%)$ than in the WEP (3\%-21\%) (Figure 7). A longer-term trend is also discernible at the two Pacific sites, with the cool-water mesotrophs indicating increasing oligotrophy over time in the WEP and increasing mesotrophy over time in the EEP. C. pelagicus, a species included in the

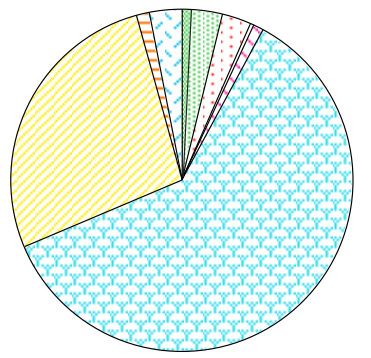

A: WEP Site 806

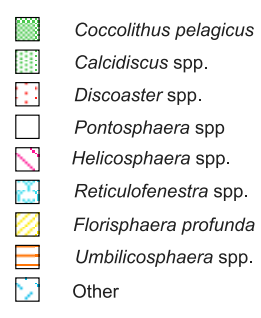

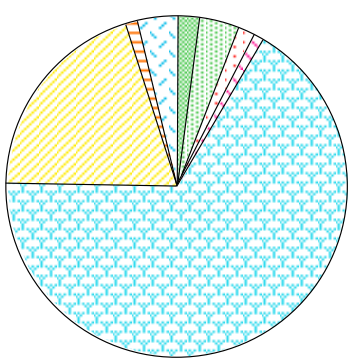

B: EEP Site 846

Figure 5. Pie charts displaying the relative contribution of different genera and species to the calcareous nannofossil assemblage averaged over the study interval at (a) ODP Site 806 and (b) ODP Site 846. 


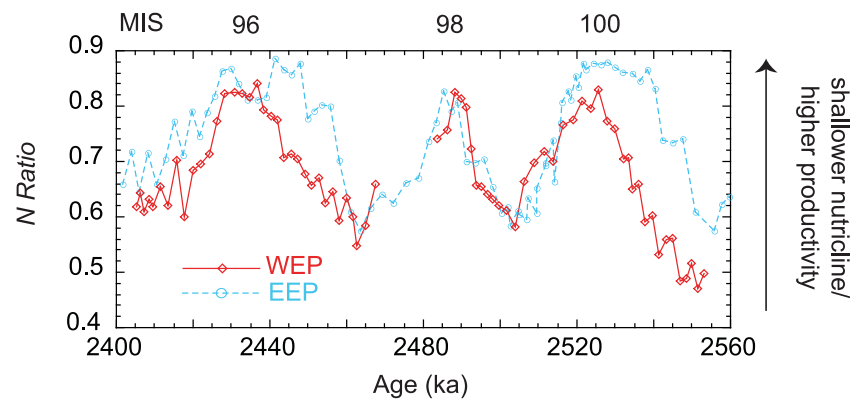

Figure 6. The $N$ ratio nutricline depth index $(N=\mathrm{VSR} /$ (VSR + Fp)) at ODP sites 806 (red diamonds and red solid line) and 846 (blue circles and blue dashed line). Higher values indicate a shallower nutricline and higher productivity in the upper photic zone.

cool-water mesotroph group, is also shown individually because, uniquely within our assemblages, its abundance patterns show strong visual correlation with precession at both sites (Figure 7).

[16] Furthermore, we also consider the relative abundances of $F$. profunda in isolation for comparison with other studies. This species accounts for, on average, $27 \%$ and $20 \%$ of the nannofossil assemblage in the WEP and EEP, respectively, with both records displaying abundance minima during glacials (Figure 7). Our late Pliocene $F$. profunda abundance ranges in the EEP are similar to those of the late
Pleistocene; however, WEP $F$. profunda abundances are substantially lower in the late Pliocene $(12 \%-43 \%)$ than the late Pleistocene (26\%-96\%) (Table S2). This suggests that the mean oceanographic state of the WEP was significantly less oligotrophic with a shallower nutrithermocline during the late Pliocene than the late Pleistocene, resulting in shallower E-W equatorial Pacific oceanographic gradients.

[17] The calcareous nannofossil assemblages in the WEP and EEP during the late Pliocene are consistent with planktic foraminiferal faunal records from ODP sites 806 and 847 that indicate a shallower WEP thermocline during the mid-Pliocene and late Pliocene than in the late Pleistocene [Chaisson, 1995; Chaisson and Ravelo, 2000]. The similar species richness at both sites is also in keeping with Plio-Pleistocene $\mathrm{Mg} / \mathrm{Ca}$ and $\delta^{18} \mathrm{O}$ data sets that imply a reduced SST gradient $\left(\sim 2^{\circ} \mathrm{C}\right)$ between the WEP and the EEP between 5.3 and 1.7 Ma [Wara et al., 2005] compared to the modern SST difference of approximately $6^{\circ} \mathrm{C}$ (Figure $1 \mathrm{c}$ ).

\subsection{Sedimentation Rates and Productivity}

[18] Sedimentation rate variations provide a first-order indication of productivity changes at our above-the-lysocline sites. On secular timescales, equatorial Pacific sedimentation patterns [Kroenke et al., 1991; Mayer et al., 1992] support our interpretation of higher productivity in the WEP and similar levels of EEP productivity during the late Pliocene as compared to the late Pleistocene. In Figure S2, we show that, for our study interval, mean glacial sedimentation rates are consistently higher than mean interglacial rates at both sites, supporting the view that productivity levels in the equatorial
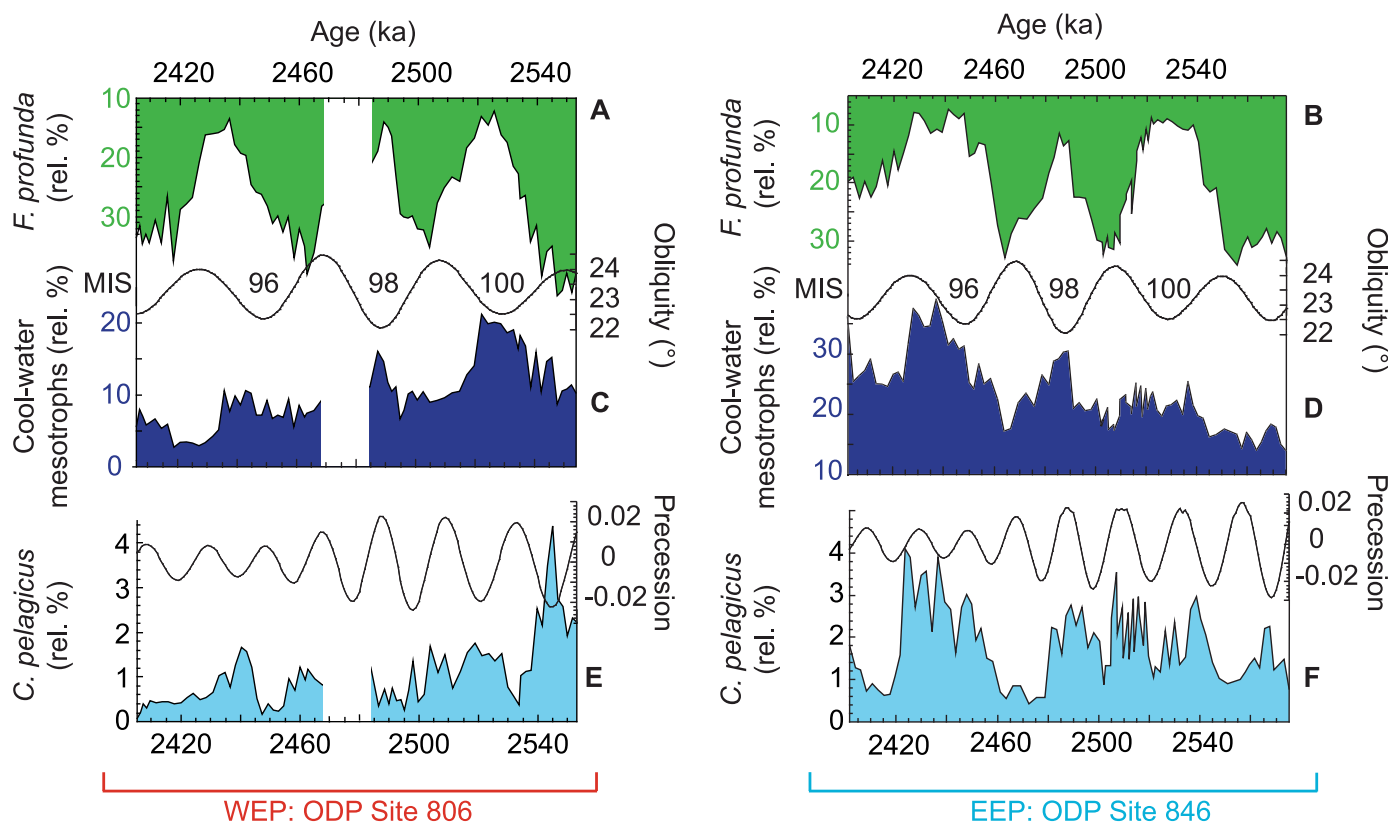

Figure 7. Species with significant orbital frequencies in their (unsmoothed) relative abundance variations: Florisphaera profunda (note inverted axis), the cool-water mesotroph group, and Coccolithus pelagicus at (a, c, e) ODP Site 806 and (b, d, f) ODP Site 846. Astronomical time series are based on work by Laskar et al. [2004] and are computed using AnalySeries [Paillard et al., 1996]. The break at $2475 \mathrm{ka}$ in the ODP Site 806 record results from a coring gap. 
Pacific were consistently enhanced during glacials relative to interglacials. The higher sedimentation rates at Site 846 compared to Site 806 during MIS 95-101 are primarily attributable to abundant diatoms at the EEP site, which occur at a diatom fragment to coccolith ratio of $\sim 1: 1$ and $\sim 0.1: 1$ during glacials and interglacials, respectively (Bolton et al., submitted manuscript, 2009). This finding implies that a higher productivity regime existed in the EEP than in the WEP. This pattern is noticeable in nannofossil assemblages, for example, by the suppressed abundance of Discoaster at the eastern site, but overall assemblage composition is similar between east and west (Figure 5). This picture is consistent with previous work on Plio-Pleistocene tropical nannofossil assemblages from varying productivity regimes [Gibbs et al., 2004a; Kinkel et al., 2000; Young, 1994], illustrating that the same species often dominate assemblages with attendant subtle changes in the contributions of subordinate species and the relative dominance of Reticulofenestra and Gephyrocapsa species versus F. profunda.

\subsection{Westward Extension of the Zone of Pacific Equatorial Divergence?}

[19] The imprint of coastal upwelling at Site 846 is readily discernible by a greater abundance of cool-water mesotrophs, marginally higher $N$ ratios, and significantly more siliceous fragments (data available on request) in the EEP than in the WEP. Alkenone, organic carbon, and bulk sediment accumulation rates from the EEP corroborate the interpretation that nutrient-rich waters were upwelling in the EEP during our study interval, despite warmer than modern SSTs [Dekens et al., 2007; Lawrence et al., 2006; Mayer et al., 1992]. In order to reconcile the similarity in terms of calcareous nannofossil assemblages that we observe between the WEP and the EEP during the late Pliocene relative to the late Pleistocene, we implicate movements of the strong salinity and $p \mathrm{CO}_{2}$ front between the WPWP and the zone of Pacific Equatorial Divergence (PEQD), a high-productivity upwelling belt along the equator. In the modern ocean, this front is estimated to sit at an average longitude of $178^{\circ} \mathrm{W}$ (Figure 2) [Le Borgne et al., 2002] and has been documented to move between $160^{\circ} \mathrm{W}$ and $170^{\circ} \mathrm{E}$ in response to climate oscillations related to ENSO [Inoue et $a l ., 1996]$. It is therefore highly plausible that this oceanographic front has shifted on longer timescales under the influence of large-scale climate change. A shallower nutricline and thermocline (this study) and about $2^{\circ} \mathrm{C}$ cooler SSTs [Wara et al., 2005] in the WEP imply that the front between the WPWP and the PEQD was located west of ODP Site $806\left(159^{\circ} \mathrm{E}\right)$ during the late Pliocene. Additionally, a comparison of sedimentation rate changes between the WEP ODP Leg 130 sites indicates that the equatorial upwelling belt was significantly wider during the late Pliocene than in the Pleistocene [Kroenke et al., 1991].

\subsection{High-Latitude Control of Equatorial Productivity}

[20] Spectral analyses of the variance of individual and grouped species abundances reveal spectral power concentrated in both the obliquity (41 kyr) and precession (19 and $23 \mathrm{kyr}$ ) bands (Figures 7 and 8). Spectral peaks at the $41 \mathrm{kyr}$ period are significant for $F$. profunda and the cool-water mesotroph group at both sites (Figures $8 \mathrm{a}-8 \mathrm{~d}$ ). In contrast, the apparent $41 \mathrm{kyr}$ cyclicity in VSR abundances is a secondary feature, the result of mirrored (opposite) variation patterns with $F$. profunda abundance, as revealed by repeat spectral analyses with $F$. profunda excluded from relative abundance calculations. The $23 \mathrm{kyr}$ precession period is expressed at significant levels at both sites by one coccolithophore species, C. pelagicus (Figures 8e and 8f). When isolated, the $C$. pelagicus variance in the precession band appears antiphased between the EEP and the WEP (Figure 9a).

[21] While $41 \mathrm{kyr}$ pacing of surface water conditions in the Pliocene and early Pleistocene EEA and EEP have been demonstrated elsewhere (see section 2.2.2), our new records from the WEP show that this high-latitude forcing paced by Earth's obliquity was a pervasive feature of tropical productivity in the late Pliocene and was not restricted to classic upwelling areas. Considered in isolation, the antiphase E-W precession components of the $C$. pelagicus data might point to an $\mathrm{E}-\mathrm{W}$ rocking of the thermocline on precessional timescales, as observed in the late Pleistocene tropical Pacific [Beaufort et al., 2001]. However, the lack of precessional power in any other species, especially the thermoclinedweller $F$. profunda, means that thermocline tilting on this timescale cannot be held to account for community-wide patterns of variance.

[22] Knowing that precession is the dominant influence on solar forcing in the tropics, the limited amount of variance in the precession band (C. pelagicus aside) implies that our records are not primarily forced by local seasonal insolation. This implicates remote (high-latitude) forcing of equatorial productivity, which is an important finding because most tropical paleoproductivity records from the late Pleistocene are dominated by regional processes driven by local insolation, [e.g., Beaufort et al., 1997, 2001; Budziak et al., 2000; Holbourn et al., 2005; Molfino and McIntyre, 1990; Perks et al., 2002; Rostek et al., 1997]. Potentially, the prevalence of obliquity-paced tropical climate records in our study might be reconciled by considering the sum of insolation anomalies over the annual cycle. Unlike precession, obliquity variations alter the mean annual insolation received at all latitudes, thereby altering the meridional insolation gradient. Nevertheless, the direct effect of orbital tilt variations on mean annual insolation is small at the equator $\left(\sim 3 \mathrm{~W} / \mathrm{m}^{2}\right.$ or an annual change of less than $0.5 \%$ [Lee and Poulsen, 2008]) and requires significant amplifiers in the climate system to translate an obliquity forcing into largescale climate change [Lee and Poulsen, 2008; Loutre et al., 2004; Raymo and Nisancioglu, 2003]. Additionally, the association of cool tropical SSTs and high productivity with obliquity minima (Figure 7) confirms that our equatorial records cannot be explained by changes in local (equatorial) mean annual insolation, which is itself $180^{\circ}$ out of phase with obliquity. This finding provides further support for remote climatic forcing of our records. In section 4.6 we evaluate a series of hypotheses capable of explaining this key observation. 

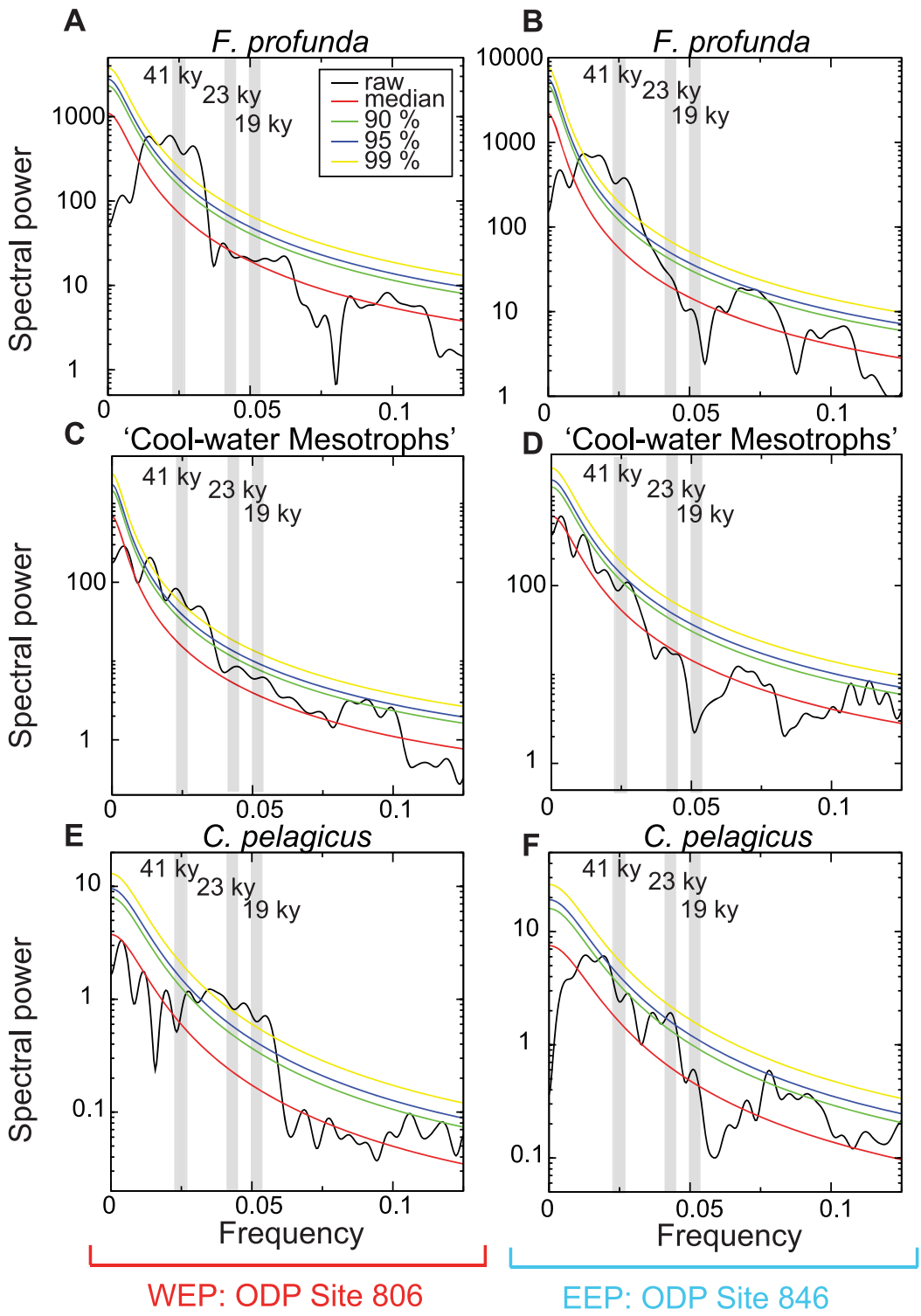

Figure 8. Spectral analyses of $F$. profunda, the cool-water mesotroph group, and C. pelagicus at (a, c, e) ODP Site 806 and (b, d, f) ODP Site 846. Grey bars represent the orbital periodicities of 41 (obliquity) and 23 and 19 (precession) kyr. Black lines are raw data. Yellow, blue, and green lines represent 99\%, $95 \%$, and $90 \%$ confidence levels, respectively. The red line shows the median of the data. Note log scale on all $y$ axes.

\subsection{Potential Mechanisms for Obliquity Control}

\subsubsection{Thermocline Ventilation}

[23] Our floral data reveal that surface productivity fluctuations on $41 \mathrm{kyr}$ timescales are in phase between the EEP and the WEP. This finding rules out the possibility that G-IG changes in productivity were controlled by E-W seesawing of the equatorial thermocline because this process would have resulted in antiphased assemblage variations. In principle, basin-wide diabatic movements of the equatorial thermocline on G-IG timescales are a second mechanism by which thermocline ventilation has the potential to impact on productivity [Fedorov et al., 2006]. The modern WEP thermocline is so deep $(>150 \mathrm{~m})$ that its vertical excursions have virtually no effect on surface waters [Turk et al., 2001]. Therefore, the similar amplitude of the G-IG productivity fluctuations that we find in the Pliocene EEP and WEP can only be explained by changes in average thermocline depth if the late Pliocene WEP thermocline was substantially shallower than its modern counterpart. Furthermore, the likelihood of basin-wide diabatic movements of the thermocline being responsible for the obliquity-paced variations that we observe gains little support from early Pleistocene studies. These reveal remarkable similarity of phasing and amplitude between SSTs in the WPWP and the EEP cold tongue on obliquity timescales at a time when E-W Pacific asymmetry in thermocline depth is thought to have been 

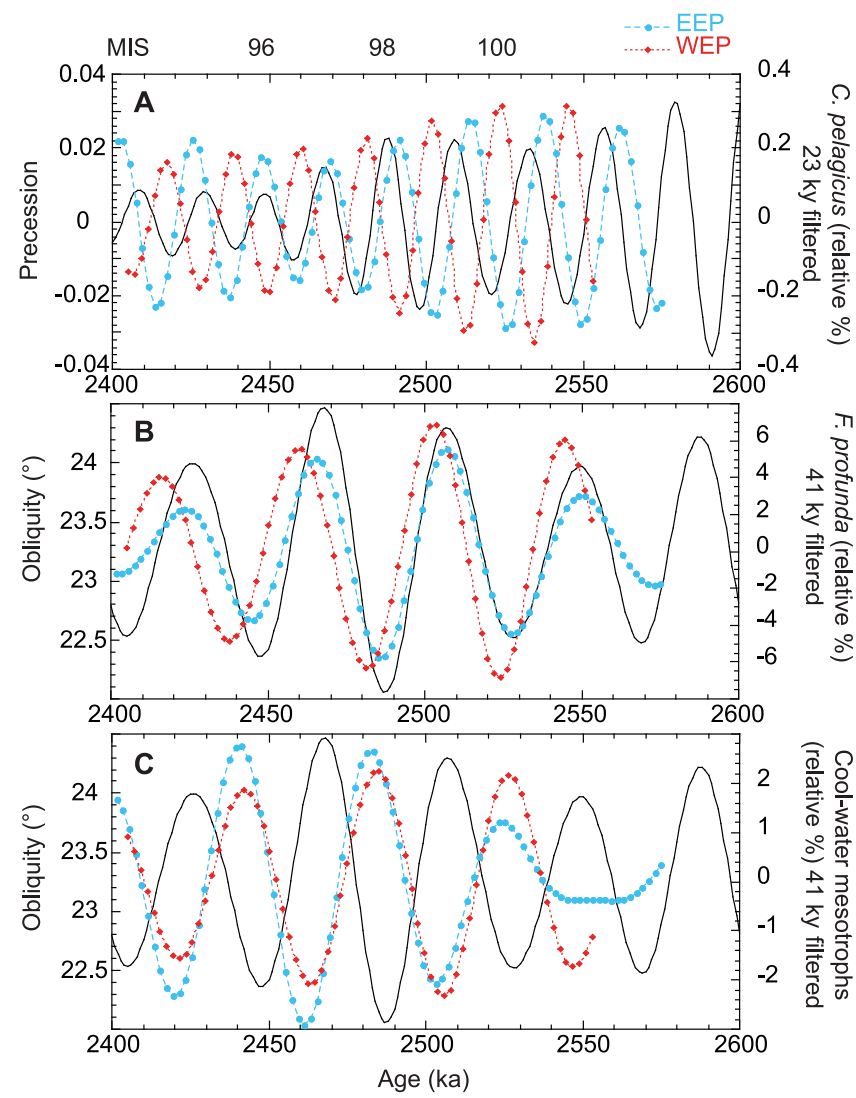

Figure 9. (a) The $23 \mathrm{kyr}$ component of the $C$. pelagicus relative abundance data at ODP sites 806 (red diamonds and red dotted line) and 846 (blue circles and blue dashed line) plotted against precession (black solid line). (b) The $41 \mathrm{kyr}$ component of $F$. profunda abundance data at ODP sites 806 and 846 plotted against obliquity. Cross-spectral analysis reveals a phase difference of $3410( \pm 1735)$ years at the $>95 \%$ confidence level in the obliquity band. (c) The $41 \mathrm{kyr}$ component of the cool-water mesotroph group abundance data at ODP sites 806 and 846 plotted against obliquity. Astronomical time series are based on work by Laskar et al. [2004] and are computed using AnalySeries [Paillard et al., 1996].

well established (section 2.1) [de Garidel-Thoron et al., 2005; Lea et al., 2000; Medina-Elizalde and Lea, 2005].

\subsubsection{Trade Wind Variability}

[24] A second hypothesis capable of explaining the obliquity-paced productivity oscillations in our records is changes in trade wind strength and their role in stimulating equatorial and coastal upwelling [Sarnthein and Winn, 1988]. Modeling studies [e.g., Bush and Philander, 1998], as well as the close coupling of SSTs and productivity on G-IG timescales during the early Pleistocene in the EEP and the EEA upwelling regions, point to stronger trades during glacials than interglacials [Cleaveland and Herbert, 2007]. However, the implication of this reasoning is a strengthening of E-W SST and sea level pressure gradients during glacials and a resultant deeper thermocline in the WEP [Bjerknes, 1969]. This is inconsistent with our near- synchronous, same-amplitude productivity variations between the WEP and the EEP and implies that changes in equatorial trade wind strength on $41 \mathrm{kyr}$ timescales could not have been large enough to significantly affect the E-W tilt of the thermocline. One would theoretically expect tropical wind fields to be dominantly forced by local insolation. However, the lack of widespread precessional power in our records either attests to comparatively minor variability in trade wind strength at precessional timescales during the late Pliocene or implies that nannofossil assemblages are relatively insensitive to this forcing in comparison to G-IG climate change and associated feedbacks at this time.

\subsubsection{Atmospheric Greenhouse Gas Concentrations}

[25] Climate model simulations for the last glacial period indicate that atmospheric $\mathrm{CO}_{2}$ concentrations are the dominant source of radiative forcing in the tropics [Broccoli and Manabe, 1987; Broccoli, 2000], and greenhouse gas concentrations are proposed as the most plausible mechanism capable of synchronizing tropical SSTs across the Pleistocene Pacific [Medina-Elizalde and Lea, 2005]. The strong correspondence documented between an EEP SST record and the Vostok ice core $\mathrm{CO}_{2}$ record provides evidence that atmospheric $\mathrm{CO}_{2}$ is the dominant control on tropical climate on orbital timescales during the late Pleistocene [Lea, 2004]. Furthermore, the consistently observed lead of several thousand years of productivity and SST over benthic $\delta^{18} \mathrm{O}$ in Plio-Pleistocene records [Gibbs et al., 2004a; Lawrence et al., 2006; Lea, 2004; Liu and Herbert, 2004; MedinaElizalde and Lea, 2005] rules out the possibility that equatorial surface water processes were directly forced by highlatitude ice sheets and their effect on the radiation budget. Therefore, a role for greenhouse gases and their associated biogeochemical feedbacks (e.g., via SST and dust fertilization changes) on $41 \mathrm{kyr}$ timescales in producing the near-synchronous, same-amplitude surface productivity fluctuations during the late Pliocene in the WEP and the EEP seems likely.

\subsubsection{Stratification Changes}

[26] Another plausible mechanism operating on obliquity timescales involves changes in the flux of nutrients from deep waters into the photic zone. An enhanced nutrient flux might result from a reduced vertical temperature gradient across the thermocline associated with lower glacial SSTs [Fedorov and Philander, 2001]. Weakened thermal stratification has been hypothesized to account for greater equatorial Pacific productivity during the late Pleistocene glacials [Beaufort et al., 2001]. We invoke the involvement of a similar mechanism to account for higher glacial biological productivity in both the WEP and the EEP during the late Pliocene. If Site 806 were located beneath the PEQD during this time as we suggest (see section 4.3), this would have created a Pacific-wide connection between surface waters and high-latitude mode waters via upwelling from the EUC.

\subsection{Top-Down and Bottom-Up Forcing on Coccolithophore Assemblages}

[27] Phase relationships between our records of paleoproductivity in the EEP and WEP provide evidence for the 
Table 1. Phase Relationships of Nannofossil Paleoproductivity Indicators and Species Between EEP and WEP Relative to the Benthic $\delta^{18} \mathrm{O}$ Record, Local Summer Insolation, F. profunda, and the $N$ Ratio ${ }^{\mathrm{a}}$

\begin{tabular}{|c|c|c|c|}
\hline Site & Parameter & 41 kyr Band & 23 kyr Band \\
\hline & & Phase Relationship Relative to Benthic $\delta^{18} O^{\mathrm{b}}$ & \\
\hline 806 & F. profunda & $11.45^{\circ}\left( \pm 11.24^{\circ}\right)=1304$ years $( \pm 1280$ years $)(>95 \%$ coherency $)$ & $14.87^{\circ}( \pm 0)=950$ years $(>80 \%$ coherency $)$ \\
\hline 806 & $\begin{array}{l}\text { Cool-water } \\
\text { mesotrophs }\end{array}$ & $-15.74^{\circ}\left( \pm 13.24^{\circ}\right)=-1819$ years $( \pm 1530$ years $)(>80 \%$ coherency $)$ & $<80 \%$ coherency \\
\hline 806 & $N$ ratio & $11.27^{\circ}\left( \pm 12.14^{\circ}\right)=1284$ years $( \pm 1383$ years $)(>95 \%$ coherency $)$ & $10.82^{\circ}( \pm 0)=691$ years $(>80 \%$ coherency $)$ \\
\hline 846 & F. profunda & $-22.36^{\circ}\left( \pm 17.97^{\circ}\right)=-2547$ years $( \pm 2047$ years $)(>95 \%$ coherency $)$ & $<80 \%$ coherency \\
\hline 846 & Cool-water mesotrophs & $-4.99^{\circ}\left( \pm 21.01^{\circ}\right)=-568$ years $( \pm 2393$ years $)(>95 \%$ coherency $)$ & $<80 \%$ coherency \\
\hline 846 & $N$ ratio & $\begin{array}{c}-23.84^{\circ}\left( \pm 19.62^{\circ}\right)=-2715 \text { years }( \pm 2235 \text { years })(>95 \% \text { coherency }) \\
\text { Phase Relationship Relative to Local Summer Insolation }\end{array}$ & $<80 \%$ coherency \\
\hline 806 & C. pelagicus & $<80 \%$ coherency & $\begin{array}{l}-74.3^{\circ}\left( \pm 25.9^{\circ}\right)=-4747 \text { years } \\
( \pm 1655 \text { years })(>80 \% \text { coherency })\end{array}$ \\
\hline 846 & C. pelagicus & $\begin{array}{l}\qquad<80 \% \text { coherency } \\
\text { Phase Relationshin Relative to Site } 846 \text { F profunda }\end{array}$ & $<80 \%$ coherency \\
\hline 806 & F. profunda & $\begin{array}{c}\text { Phase Relationship Relative to Site } 846 \mathrm{~F} \text {. profunda } \\
29.94^{\circ}\left( \pm 15.23^{\circ}\right)=3410 \text { years }( \pm 1735 \text { years })(>95 \% \text { coherency }) \\
\text { Phase Relationship Relative to Site } 846 \text { N Ratio }\end{array}$ & $<80 \%$ coherency \\
\hline 806 & $N$ ratio & $29.63^{\circ}\left( \pm 16.40^{\circ}\right)=3375$ years $( \pm 1868$ years $)(>95 \%$ coherency $)$ & $<80 \%$ coherency \\
\hline
\end{tabular}

${ }^{a}$ Positive values indicate a lead of $\delta^{18} \mathrm{O}$ (ice volume) over nannofossil proxies, and negative values indicate a lead of nannofossil proxies over $\delta^{18} \mathrm{O}$.

${ }^{\mathrm{b}}$ Benthic $\delta^{18} \mathrm{O}$ record of Site 846 [Shackleton et al., 1995] is tuned to the LR04 benthic oxygen isotope stack [Lisiecki and Raymo, 2005].

${ }^{\mathrm{c}} \mathrm{S}$ ummer insolation is from 21 June to 21 September. Relationships are computed at $3^{\circ} \mathrm{S}$ for EEP runs and $0.2^{\circ} \mathrm{N}$ for WEP runs using AnalySeries [Paillard et al., 1996].

imprint of at least two mechanisms operating on obliquity timescales (Table 1 and Figure 9). In Figures 9b and 9c, we filter our $F$. profunda and cool-water mesotroph abundance records, leaving only the obliquity components of these series. Of note are the close phasing between high-latitude obliquity variations and $F$. profunda abundances (Figure 9b) and also the near-antiphase behavior of the cool-water mesotrophs at both sites with respect to obliquity (Figure 9c). Figure 9b illustrates the $3.4( \pm 1.7)$ kyr phase difference between EEP and WEP $F$. profunda abundances in the obliquity band. Consideration of this phase difference in the thermocline dwellers while the surface dwellers vary in phase between east and west implies the interaction of two different mechanisms both varying on obliquity timescales: (1) a "top-down" forcing that acts on equatorial Pacific surface waters in a uniform manner (namely, atmospheric greenhouse gas concentrations) and (2) a "bottomup" forcing being transmitted via the thermocline from deeper waters, the effect of which is somehow felt in the EEP before it reaches the WEP (namely, stratification changes). This bottom-up forcing likely originates in southern high latitudes because the upwelling of subantarctic mode waters from the EUC provides a direct connection between the equatorial Pacific and the Southern Ocean [Harper, 2000; Sarmiento et al., 2004].

\section{Summary and Conclusions}

[28] Calcareous nannofossil records from the WEP and the EEP over three obliquity-paced G-IG cycles reveal large-amplitude, near-synchronous variations in late Pliocene nutricline depth and productivity. The following are our key findings.

[29] 1. We report remarkably similar nannofossil assemblages in terms of species richness and composition in both of our equatorial Pacific sites. This result attests to reduced E-W equatorial Pacific oceanographic gradients as previ- ously inferred from SST and faunal data sets during the late Pliocene relative to today.

[30] 2. We find that the WEP nutricline and thermocline was shallower during the late Pliocene than during the late Pleistocene. We suggest that this results from a more westward position of the front between the WPWP and the PEQD than today, implicating upwelling from the EUC into the surface waters overlying Site 806 during our study interval.

[31] 3. Limited evidence for local (precessional) forcing of productivity is found at both sites. However, the main orbital variance in nannofossil assemblages occurs in the obliquity band, implicating remote (high-latitude) control of Pliocene tropical productivity in both the western and eastern equatorial Pacific.

[32] 4. We find no evidence for productivity control by either E-W tilting or basin-wide diabatic movements of the thermocline with important implications for the debate over the operation of ENSO-like dynamics in the Pliocene tropical Pacific.

[33] 5. We find a $3.4( \pm 1.7)$ kyr phase difference between EEP and WEP thermocline-dwelling nannofossils while photic zone assemblages vary in phase with one another at the two sites. This implicates the operation of top-down (atmospheric $\mathrm{CO}_{2}$ ) and bottom-up (nutrient supply) teleconnections between the high latitudes and the tropics.

[34] Acknowledgments. This work used samples provided by the Ocean Drilling Program (ODP). The ODP (now IODP) is sponsored by the U.S. National Science Foundation and participating countries under management of the Joint Oceanographic Institutions (JOI), Inc. We thank T. Bickert for allowing us to use his data prior to its publication. C.T.B was funded by a Natural Environmental Research Council (NERC) studentship (reference NER/S/A/2006/14218). S.J.G acknowledges NERC and Royal Society university research fellowships. We thank Tim Herbert, Kira Lawrence, Heiko Pälike, Toby Tyrrell, and Alan Kemp for helpful discussions. We are grateful to Jan Backman and Alan Haywood for their constructive reviews. C.T.B thanks R. Kasicki for assistance with graphics. P.A.W. acknowledges NERC UK IODP grants. 


\section{References}

Backman, J., and N. J. Shackleton (1983), Quantitative biochronology of Pliocene and early Pleistocene calcareous nannofossils from the Atlantic, Indian and Pacific oceans, Mar. Micropaleontol., 8, 141-170, doi:10.1016/ 0377-8398(83)90009-9.

Barreiro, M., G. Philander, R. Pacanowski, and A. Fedorov (2006), Simulations of warm tropical conditions with application to middle Pliocene atmospheres, Clim. Dyn., 26, 349-365, doi:10.1007/s00382-005-0086-4.

Beaufort, L., Y. Lancelot, P. Camberlin, O. Cayre, E. Vincent, F. Bassinot, and L. Labeyrie (1997), Insolation cycles as a major control of equatorial Indian Ocean primary production, Science, 278, 1451-1454, doi:10.1126/science.278.5342.1451.

Beaufort, L., T. de Garidel-Thoron, A. C. Mix, and N. G. Pisias (2001), ENSO-like forcing on oceanic primary production during the late Pleistocene, Science, 293, 2440-2444, doi:10.1126/science.293.5539.2440.

Berger, W. H., M.-C. Bonneau, and F. L. Parker (1982), Foraminifera on the deep-sea floor: Lysocline and dissolution rate, Oceanol. Acta, $5,249-258$.

Bjerknes, J. (1969), Atmospheric teleconnections from the equatorial Pacific, Mon. Weather Rev., 97(3), 163-172, doi:10.1175/ 1520-0493(1969)097<0163:ATFTEP >2.3. $\mathrm{CO} ; 2$.

Blaj, T., J. Backman, and I. Raffi (2009), Late Eocene to Oligocene preservation history and biochronology of calcareous nannofossils from paleo-equatorial Pacific Ocean sediments, Riv. Ital. Paleontol. Stratigr., 115(1), 67-85.

Bown, P. R., and J. R. Young (1998), Techniques, in Calcareous Nannofossil Biostratigraphy, edited by P. R. Bown, chap. 2, pp. 16-28, Kluwer Acad., Dordrecht, Netherlands.

Broccoli, A. J. (2000), Tropical cooling at the last glacial maximum: An atmosphere-mixed layer ocean model simulation, J. Clim., 13(5), 951-976, doi: 10.1175/1520-0442(2000) 013<0951:TCATLG $>2.0$. CO 2 .

Broccoli, A. J., and S. Manabe (1987), The effects of the Laurentide ice sheet on North American climate during the Last Glacial Maximum, Geogr. Phys. Quat., 47(2), 291299.

Budziak, D., R. R. Schneider, F. Rostek, P. J. Muller, E. Bard, and G. Wefer (2000), Late Quaternary insolation forcing on total organic carbon and $\mathrm{C}_{37}$ alkenone variations in the Arabian Sea, Paleoceanography, 15, 307-321, doi:10.1029/1999PA000433.

Bush, A. B. G., and S. G. H. Philander (1998), The role of ocean-atmosphere interactions in tropical cooling during the Last Glacial Maximum, Science, 279, 1341-1344, doi:10.1126/ science.279.5355.1341.

Cane, M. A. (1998), Climate change: A role for the tropical Pacific, Science, 282, 59-61, doi:10.1126/science.282.5386.59

Cane, M. A. (2005), The evolution of El Niño, past and future, Earth Planet. Sci. Lett., 230, 227-240, doi:10.1016/j.eps1.2004.12.003.

Chaisson, W. P. (1995), Planktonic foraminiferal assemblages and paleoceanographic change in the trans-tropical Pacific Ocean: A comparison of west (Leg 130) and east (Leg 138), latest Miocene to Pleistocene, Proc. Ocean Drill. Program Sci. Results, 138, 555-597, doi:10.2973/odp.proc.sr.138.129.1995.
Chaisson, W. P., and A. C. Ravelo (2000), Pliocene development of the east-west hydrographic gradient in the equatorial Pacific, Paleoceanography, 15, 497-505, doi:10.1029/ 1999PA000442.

Chavez, F. P., and R. T. Barber (1987), An estimate of new production in the equatorial Pacific, Deep Sea Res., Part A, 34, 1229-1243, doi:10.1016/0198-0149(87)90073-2.

Chiyonobu, S., T. Sato, R. Narikiyo, and M. Yamasaki (2006), Floral changes in calcareous nannofossils and their paleoceanographic significance in the equatorial Pacific Ocean during the last 500000 years, Isl. Arc, 15, 476482, doi:10.1111/j.1440-1738.2006.00543 x.

Cleaveland, L. C., and T. D. Herbert (2007), Coherent obliquity band and heterogeneous precession band responses in early Pleistocene tropical sea surface temperatures, Paleoceanography, 22, PA2216, doi:10.1029/ 2006PA001370.

de Garidel-Thoron, T., L. Beaufort, B. K. Linsley, and S. Dannenmann (2001), Millennial-scale dynamics of the East Asian winter monsoon during the last 200,000 years, Paleoceanography, 16, 491-502, doi:10.1029/2000PA000557.

de Garidel-Thoron, T., Y. Rosenthal, F. Bassinot, and L. Beaufort (2005), Stable sea surface temperature in the western Pacific warm pool over the past 1.75 million years, Nature, 433, 294-298, doi:10.1038/nature03189.

Dekens, P. S., A. C. Ravelo, and M. D. McCarthy (2007), Warm upwelling regions in the Pliocene warm period, Paleoceanography, 22, PA3211, doi:10.1029/2006PA001394.

Falkowski, P. G., R. T. Barber, and V. Smetacek (1998), Biogeochemical controls and feedbacks on ocean primary production, Science, 281 , 200-206, doi:10.1126/science.281.5374.200

Fedorov, A. V., and G. S. Philander (2001), A stability analysis of tropical ocean-atmosphere interactions: Bridging measurements and theory for El Niño, J. Clim., 14, 3086-3101, doi:10.1175/1520-0442(2001)014<3086: ASAOTO $>2.0 . C O ; 2$

Fedorov, A. V., P. S. Dekens, M. McCarthy, A. C. Ravelo, P. B. deMenocal, M. Barreiro, R. C. Pacanowski, and S. G. Philander (2006), The Pliocene paradox (mechanisms for a permanent El Niño), Science, 312, 1485-1489, doi:10.1126/science.1122666.

Findlay, C. S., and J. Giraudeau (2002), Movement of oceanic fronts south of Australia during the last $10 \mathrm{ka}$ : Interpretation of calcareous nannoplankton in surface sediments from the Southern Ocean, Mar. Micropaleontol., 46, 431-444, doi:10.1016/S0377-8398(02) $00084-1$.

Flores, J. A., F. J. Sierro, and I. Raffi (1995), Evolution of the calcareous nannofossil assemblage as a response to the paleoceanographic changes in the eastern equatorial Pacific Ocean from 4 to 2 Ma (Leg 138, Sites 849 and 852), Proc. Ocean Drill. Program Sci. Results, 138,163-176, doi:10.2973/odp.proc. sr.138.109.1995.

Flores, J.-A., M. A. Bárcena, and F. J. Sierro (2000), Ocean-surface and wind dynamics in the Atlantic Ocean off northwest Africa during the last 140000 years, Palaeogeogr. Palaeoclimatol. Palaeoecol., 161, 459-478, doi:10.1016/ S0031-0182(00)00099-7.

Foster, G. L., O. Seki, D. N. Schmidt, K. Kawamura, and R. Pancost (2008), PlioPleistocene $p \mathrm{CO}_{2}$ : A multiproxy approach using alkenone and boron based carbonate system proxies, Eos Trans. AGU, 89(53), Fall Meet. Suppl., Abstract PP41D-1484.

Ghil, M., et al. (2002), Advanced spectral methods for climatic time series, Rev. Geophys., 40(1), 1003, doi:10.1029/2000RG000092.

Gibbs, S., N. Shackleton, and J. Young (2004a), Orbitally forced climate signals in mid-Pliocene nannofossil assemblages, Mar. Micropaleontol., 51, 39-56, doi:10.1016/j.marmicro.2003.09.002.

Gibbs, S., N. Shackleton, and J. Young (2004b), Identification of dissolution patterns in nannofossil assemblages: A high-resolution comparison of synchronous records from Ceara Rise ODP Leg 154, Paleoceanography, 19 , PA1029, doi:10.1029/2003PA000958.

Hagelberg, T. K., N. Pisias, L. A. Mayer, N. Shackleton, and A. C. Mix (1995), Spatial and temporal variability of late Neogene equatorial Pacific carbonare: Leg 138, Proc. Ocean Drill. Program Sci. Results, 138, 321-336, doi:10.2973/odp.proc.sr.138.116.1995

Harper, S. (2000), Thermocline ventilation and pathways of tropical-subtropical water mass exchange, Tellus, Ser. A, 52, 330-345, doi:10.1034/j.1600-0870.2000.d01-7.x.

Haywood, A. M., P. J. Valdes, and V. L. Peck (2007), A permanent El Niño-like state during the Pliocene?, Paleoceanography, 22, PA1213, doi:10.1029/2006PA001323.

Holbourn, A., W. Kuhnt, H. Kawamura, Z. Jian, P. Grootes, H. Erlenkeuser, and J. Xu (2005), Orbitally paced paleoproductivity variations in the Timor Sea and Indonesian Throughflow variability during the last $460 \mathrm{kyr}$, Paleoceanography, 20, PA3002, doi:10.1029/ 2004PA001094.

Howell, P., N. Pisias, J. Ballance, J. Baughman, and L. Ochs (2006), Arand time-series analysis software, Brown Univ., Providence, R. I.

Inoue, H. Y., M. Ishii, H. Matsueda, and M. Ahoyama (1996), Changes in longitudinal distribution of the partial pressure of $\mathrm{CO}_{2}$ $\left(p \mathrm{CO}_{2}\right)$ in the central and western equatorial Pacific, west of $160^{\circ} \mathrm{W}$, Geophys. Res. Lett. 23, 1781-1784, doi:10.1029/96GL01674.

Karas, C., D. Nürnberg, A. K. Gupta, R. Tiedemann, K. Mohan, and T. Bickert (2009), Mid-Pliocene climate change amplified by a switch in Indonesian subsurface throughflow, Nat. Geosci., 2, 434-438, doi:10.1038/ ngeo520.

Kessler, W. S. (2006), The circulation of the eastern tropical Pacific: A review, Prog. Oceanogr., 69, 181-217, doi:10.1016/j.pocean.2006.03.009.

Kinkel, H., K.-H. Baumann, and M. Cepek (2000), Coccolithophores in the equatorial Atlantic Ocean: Response to seasonal and late Quaternary surface water variability, Mar Micropaleontol., 39, 87-112, doi:10.1016 S0377-8398(00)00016-5.

Kroenke, L. W., et al. (Eds.) (1991), Proceedings of the Ocean Drilling Program, Initial Reports, vol. 130, Ocean Drill. Program, College Station, Tex.

Laskar, J., P. Robutel, F. Joutel, M. Gastineau, A. C. M. Correia, and B. Levrard (2004), A long term numerical solution for the insolation quantities of the Earth, Astron. Astrophys., 428, 261-285, doi:10.1051/0004-6361:20041335.

Lawrence, K. T., Z. Liu, and T. D. Herbert (2006), Evolution of the eastern tropical Pacific through Plio-Pleistocene glaciation, Science, 312, 7983, doi:10.1126/science.1120395. 
Lea, D. W. (2004), The 100000-yr cycle in tropical SST, greenhouse forcing, and climate sensitivity, J. Clim., 17, 2170-2179, doi:10.1175/ 1520-0442(2004)017<2170:TYCITS $>2.0$. $\mathrm{CO} ; 2$

Lea, D. W., D. K. Pak, and H. J. Spero (2000), Climate impact of late Quaternary equatorial Pacific sea surface temperature variations, Science, 289, 1719-1724, doi:10.1126/science.289.5485.1719.

Le Borgne, R., R. T. Barber, T. Delcroix, H. Y. Inoue, D. J. Mackey, and M. Rodier (2002), Pacific warm pool and divergence: Temporal and zonal variations on the equator and their effects on the biological pump, Deep Sea Res., Part II, 49, 2471-2512, doi:10.1016/ S0967-0645(02)00045-0.

Lee, S.-Y., and C. J. Poulsen (2008), Amplification of obliquity forcing through mean annual and seasonal atmospheric feedbacks, Clim. Past, 4, 205-213.

Lisiecki, L. E., and M. E. Raymo (2005), A Pliocene-Pleistocene stack of 57 globally distributed benthic $\delta^{18} \mathrm{O}$ records, Paleoceanography, 20, PA1003, doi:10.1029/2004PA001071.

Liu, Z., and T. D. Herbert (2004), High-latitude influence on the eastern equatorial Pacific climate in the early Pleistocene epoch, Nature, 427, 720-723, doi:10.1038/nature02338.

López-Otálvaro, G.-E., J.-A. Flores, F. J. Sierro, and I. Cachao (2008), Variations in coccolithophorid production in the eastern equatorial Pacific at ODP Site 1240 over the last seven glacial-interglacial cycles, Mar. Micropaleontol., 69, 52-69, doi:10.1016/j.marmicro.2007.11.009.

Loutre, M.-F., D. Paillard, F. Vimeux, and E. Cortijo (2004), Does mean annual insolation have the potential to change the climate?, Earth Planet. Sci. Lett., 221, 1-14, doi:10.1016/S0012-821X (04)00108-6

Lunt, D. J., G. L. Foster, A. M. Haywood, and E. J. Stone (2008), Late Pliocene Greenland glaciation controlled by a decline in atmospheric $\mathrm{CO}_{2}$ levels, Nature, 454, 1102-1106, doi: 10.1038 /nature 07223

Matsuoka, H. (1990), A new method to evaluate dissolution of $\mathrm{CaCO}_{3}$ in the deep-sea sediments, Trans. Proc. Palaeontol. Soc. Jpn., 157, 430-434.

Mayer, L. A., et al. (1992), Proceedings of the Ocean Drilling Program, Initial Results, vol. 138, Ocean Drill. Program, College Station, Tex.
McIntyre, A., and R. McIntyre (1971), Coccolith concentrations and differential solution in oceanic sediments, in The Micropalaeontology of Oceans: Proceedings of the Symposium Held in Cambridge From 10 to 17 September 1967 Under the Title Micropalaeontology of Marine Bottom Sediments, edited by B. M. Funnel and W. R. Riedel, pp. 253-261, Cambridge Univ. Press, Cambridge, U. K.

Medina-Elizalde, M., and D. W. Lea (2005), The mid-Pleistocene transition in the tropical Pacific, Science, 310, 1009-1012, doi:10.1126/ science. 1115933.

Mix, A. C., S. E. Harris, and T. R. Janecek (1995), Estimating lithology from nonintrusive reflectance spectra: Leg 138, Proc. Ocean Drill. Program Sci. Results, 138, 413-427, doi:10.2973/odp.proc.sr.138.116.1995.

Mix, A. C., et al. (2003), Proceedings of the Ocean Drilling Program, Initial Reports, vol. 202, Ocean Drill. Program, College Station, Tex.

Molfino, B., and A. McIntyre (1990), Precessional forcing of nutricline dynamics in the equatorial Atlantic, Science, 249, 766-769, doi:10.1126/science.249.4970.766.

Murray, D. W., J. W. Farrell, and V. McKenna (1995), Biogenic sedimentation at Site 847, eastern equatorial Pacific Ocean, during the past 3 M.Y., Proc. Ocean Drill. Program Sci. Results, 138, 429-459, doi:10.2973/odp. proc.sr.138.122.1995.

Paillard, D., L. Labeyrie, and P. Yiou (1996), Macintosh program performs time-series analysis, Eos Trans. $A G U, 77,379$, doi:10.1029/ 96EO00259.

Perch-Nielsen, K. (1985), Cenozoic calcareous nannofossils, in Plankton Stratigraphy, edited by H. M. Bolli et al., pp. 427-554, Cambridge Univ. Press, Cambridge, U. K.

Perks, H. M., C. D. Charles, and R. F. Keeling (2002), Precessionally forced productivity variations across the equatorial Pacific, Paleoceanography, 17(3), 1037, doi:10.1029/ 2000PA000603

Philander, S. G. H., and A. V. Fedorov (2003), Role of tropics in changing the response to Milankovitch forcing some three million years ago, Paleoceanography, 18(2), 1045 , doi:10.1029/2002PA000837.

Ravelo, A. C., P. S. Dekens, and M. McCarthy (2006), Evidence for El Niño-like conditions during the Pliocene, GSA Today, 16(3), 4-11, doi: $10.1130 / 1052-5173(2006) 016<4$ : EFENLC $>2.0 . \mathrm{CO} ; 2$.

Raymo, M. E., and K. Nisancioglu (2003), The 41 kyr world: Milankovitch's other unsolved mystery, Paleoceanography, 18(1), 1011, doi:10.1029/2002PA000791.

Rostek, F., E. Bard, L. Beaufort, C. Sonzogni, and G. M. Ganssen (1997), Sea surface temperature and productivity records for the past $240 \mathrm{kyr}$ in the Arabian Sea, Deep Sea Res. Part II, 44, 1461-1480, doi:10.1016/S09670645(97)00008-8.

Sarmiento, J. L., N. Gruber, M. A. Brzezinski, and J. P. Dunne (2004), High-latitude controls of thermocline nutrients and low latitude biological productivity, Nature, 427, 56-60, doi: 10.1038 /nature02127.

Sarnthein, M., and K. Winn (1988), Global variations of surface ocean productivity in low and mid latitudes: Influence on $\mathrm{CO}_{2}$ reservoirs of the deep ocean and atmosphere during the last 21000 years, Paleoceanography, 3, 361399, doi:10.1029/PA003i003p00361.

Shackleton, N. J., M. A. Hall, and D. Pate (1995), Pliocene stable isotope stratigraphy of Site 846, Proc. Ocean Drill. Program Sci. Results, 138, 337-355, doi:10.2973/odp.proc. sr.138.117.1995.

Turk, D., M. J. McPhaden, A. J. Busalacchi, and M. R. Lewis (2001), Remotely sensed biological production in the equatorial Pacific, Science, 293, 471-474, doi:10.1126/science.1056449.

Wara, M. W., A. C. Ravelo, and M. L. Delaney (2005), Permanent El Niño-like conditions during the Pliocene warm period, Science, 309, 758-761, doi:10.1126/science.1112596.

Young, J. R. (1994), Function of coccoliths, in Coccolithophores, edited by A. Winter and W. G. Siesser, pp. 63-82, Cambridge Univ. Press, Cambridge, U. K.

Young, J. R. (1998), Neogene, in Calcareous Nannofossil Biostratigraphy, edited by P. R. Bown, chap. 8, pp. 225-265, Kluwer Acad. Dordrecht, Netherlands.

C. T. Bolton, S. J. Gibbs, and P. A. Wilson, School of Ocean and Earth Science, National Oceanography Centre, Southampton, University of Southampton, Waterfront Campus, European Way, Southampton SO14 3ZH, UK. (ctb@noc. soton.ac.uk) 